\title{
Mischaracterization of the Urban Uprising, and why it matters
}

\author{
Judson L. Jeffries *
}

\begin{tabular}{|c|c|}
\hline A R T I C L E I N F O & A B S T R A C T \\
\hline $\begin{array}{l}\text { Received: April 16, } 2020 . \\
\text { Received in revised form: } \\
\text { June } 17,2020 .\end{array}$ & $\begin{array}{l}\text { This work argues the importance of distinguishing between } \\
\text { riots and urban uprisings. As this article demonstrates, riots } \\
\text { and uprisings are two very different animals with their } \\
\text { origins grounded in and amid very different circumstances. }\end{array}$ \\
\hline $\begin{array}{l}\text { Accepted: November } 11, \\
2020 . \\
\text { Published online: } \\
\text { November } 15,2020\end{array}$ & $\begin{array}{l}\text { The failure to acknowledge this difference impacts the way } \\
\text { in which rebels are portrayed, how history is told and } \\
\text { written, as well as the basis upon which public policy } \\
\text { decisions are made. }\end{array}$ \\
\hline
\end{tabular}

Key words: riots - urban uprisings media misrepresentation - police brutality

To cite this article: Jeffries, J.L., (2020). Mischaracterization of the Urban Uprising, and why it matters. Urbana, XXI. Retrieved from http://www.urbanauapp.org/

https://doi.org/10.47785/urbana.3.2020

* Judson L. Jeffries, PhD Professor The Ohio State University jeffries.70@osu.edu 


\section{Introduction}

The 1960s was one of the most tumultuous decades in modern history; tragically, it included assassinations of both grassroots and national leaders, here in the U.S. and abroad. Among those whose lives were snuffed out prematurely include Patrice Lumumba in the Congo (1960), Civil Rights leader Medgar Evers in Mississippi (1963), President John F. Kennedy (1963), Minister Malcolm X (1965), Dr. Ernesto 'Che” Guevara (1967), Dr. Martin Luther King, Jr. (1968) and Democratic presidential hopeful Robert Kennedy in June of that same year. One could argue that each man's death left a void that has yet to be filled. The decade also included revolutions, both failed and successful, as well as minor and major skirmishes and uprisings, worldwide. New theories were introduced that attempted to explain why men rebel. ${ }^{1}$ Many of the scholars whose works are considered canonical in sociology, urban politics, political science, public policy and history made their bones writing about that era (Castenada and Schneider, 2017; Feagin and Hahn, 1973; Gurr, 1970). On the matter of urban violence and revolts there was no shortage of books and other scholarly efforts. However, what scholars did not spend a great deal of time focusing on was making a distinction between riots and other expressions of urban upheaval.

Over the past forty years, scholarly interest in American rebellions in the U.S. has been sporadic, so much so, that it has deprived the academy of well-informed studies correlating collective upheaval with specific developments in politics, on both the local, state and national level. Aside from marking the anniversaries of certain major uprisings with a timely popular magazine expose or scholarly journal article, this topic of study has, for whatever reason, not experienced a resurgence. The violence that erupted in Los Angeles in the early 1990s did however reignite the intellectual curiosity of some scholars and intellectuals from disciplines ranging from Africana Studies to Medi Studies. Not since the 1960s, had an urban disorder elicited so much academic attention. Books sprouted up everywhere, many of them authored by historians, political scientists, journalists and sociologists (Cannon, 1997; Hunt, 1996; Madhubuti, 1993; Lowry and Morrison, 1992).

\section{Miami, Florida and the case of Arthur McDuffie}

Aside from the three-day disorder in May of 1980 in Miami, the 1980s saw little in way of urban uprisings, in part because the 1980s saw an increasing interest in the structural preconditions for urban politics, such as local political economy and the behavior of organized interests at the local level (Stone, 1989). Be that as it may, the upheaval, which occurred mostly in the Liberty City area of Miami was touched off by the acquittal of white police officers on trial for the brutal murder of Arthur McDuffie, a 33-year-old African American ${ }^{2}$ insurance agent and former United States Marine. McDuffie was beaten into a coma by up to a dozen white Dade County police officers after he ran a traffic light on his motorcycle and led police on a high-speed chase. The officers immediately tried to cover up their crime, staging it as an accident. McDuffie died days later from his injuries. An investigation led to arrests, but five months after McDuffie was buried, an allwhite jury in Tampa exonerated several police officers, setting off the most significant upheaval of the decade (Griffin, 2020).

Although more unrest would follow in Miami, in the years to come, both in $1982^{3}$ and $1989^{4}$ as a result of police shootings of Black residents, it was the murder of McDuffie that piqued 
the interest of some intellectuals within the academic community who in turn devoted articles and book-length treatments to the goings-on in Miami, but, overall, interest in urban rebellions within scholarly circles did not necessarily enjoy a resurgence (Griffin, 2020; Porter and Dunn, 1984). This could very well be attributed to the fact that because there were few uprisings and significantly fewer people participating in high-profile street theater and demonstrations in the 1980s, scholars did not believe there was sufficient material or reason to revisit this line of research. If this was indeed the logic, it is difficult to counter, for, when compared to the previous twenty years, the 1960s were chock full of uprisings, large and small.

It has not been easy to determine exactly the number of urban insurrections during that decade. Brian Downes (1970) states, for example, that from 1964 to 1968 there were 329 uprisings in 257 cities. The Civil Disorder Clearing House counted, for 1967 alone, 233 disorders in 168 cities. Joe Feagin and Harlan Hahn (1973) noted in their Pulitzer prize nominated work Ghetto Revolts that in a single month following the assassination of Dr. Martin Luther King, Jr., no less than 220 disorders occurred in 172 cities. Whatever the exact numbers, what is clear is that a sizeable portion of the African American community was dissatisfied with the way things were and expressed that dissatisfaction in an assertive manner. Ted Gurr approximated that Americans averaged 5,400 man-days of participation in protest (demonstrations and uprisings) per 100,000 population (Gurr, 1989). For many students of urban politics and sociology, America's highly populated urban areas proved to be a most popular unit of analysis, in part, due to the influx of Black residents brought about by the great migration. In other words, some scholars sought to capitalize on this development by using many of the country's big cities as a laboratory for academic self-promotion, rather than as an opportunity to bring about real change.

\section{Urban uprisings and their historic roots}

In last five years or so, a number of cities of varying size have experienced violent protests that have lasted for several days, yet the enthusiasm among scholars to examine these case studies is not what it once was. Why that is so is unclear. Perhaps the infrequency with which these uprisings have occurred have not produced a large enough sample size to allow for the kind of generalizability desired by many scholars, especially those in the social sciences. The result: Both the scholarly community and the general public are poorer for it, neither of which, for the most part, appear equipped to properly contextualize the recent violence or situate it within the larger, historical context of so-called American Democracy.

In light of the protests that have occurred in many major cities across America since the murders of Breonna Taylor in Kentucky and George Floyd in Minnesota, there seems no better time than now to revisit a topic that was a major area of study during the 1960s. What we have witnessed unfold on the streets of America over the course of the past several months has, more often than not, been characterized as riots, most notably by reporters and journalists. So-called experts on urban politics, both white as well as people of color, have also been complicit in this depiction. This, in large part, accounts for the shallow manner in which these events are presented and discussed within the general public as well as academic circles. This writer has witnessed 
countless interviews of talking heads who repeatedly mischaracterized these aggressive streetlevel protests, that in some cases, have been accompanied by looting and destruction of property, as riots.

In this article I argue that what we've been witnessing over the past several months in cities such as Louisville, Portland, Vancouver, New York, Los Angeles, Minneapolis and many more are not riots, but something far more substantial, with a deeper socio-political meaning from which important lessons can be gleaned and informed public policy formulated.

Before embarking on said discussion, it is important to put Black led or initiated uprisings in context. Black initiated or led uprisings are deeply rooted in the slave rebellions of the $18^{\text {th }}$ and $19^{\text {th }}$ centuries. The first reported slave rebellion occurred in Manhattan in 1712 but was extinguished with great force. More than two decades later, down south, the state of South Carolina experienced the Stono Rebellion, and, in 1741, New Yorkers were once again consumed with fear of a slave uprising. The fear was palpable, and the result was that white men embarked on a hysterical rampage in which tens of Blacks were shot, burned, hanged or run out of town. There were two other planned major uprisings that deserve mention-one by Gabriel Prosser in Richmond, Virginia (1800), and the other led by Denmark Vesey in Charleston, South Carolina (1822); as well as two major actual rebellions by Louisiana slaves, in St. Charles and St. John the Baptist parishes (1811), and by slaves in Southampton County, Virginia (1831) under the leadership of the Reverend Nat Turner about whom many books have been written. For reasons that are hard to understand, Turner's uprising is better known than the single most successful act of large-scale violent resistance to slavery on the part of American blacks: the case of the Florida Maroons who, in tandem with Seminole Indians, in 1838, successfully fought to maintain their status as escapees from white servitude (Millett, 2013; Mulroy, 1993). These uprisings can be no more characterized as riots than the developments that have erupted in urban areas over the past several months.

\section{A Riot is ... riots and their various iterations}

Riots are violent public disturbances, comprised of an indeterminate number of people, that are frivolous in nature. The ruckus lacks political purpose and is therefore senseless, and without meaning. The destruction of property as well as violence against human beings is unjustified, irresponsible and without cause. Riots manifest in myriad ways. What follows is a typology created by the author that divides riots into three sub-categories - Riots Without Meaning (RWM), Socially Oppressive Riots (SOR) and Political Repressive Riots (PRR).

The most common Riot Without Meaning occurs when silly and often inebriated sports fans, usually white, celebrate their team's win (oftentimes a championship) in a most curious way, that is, setting objects on fire, breaking the windows of nearby buildings and establishments, vandalizing property and turning over cars. The revelers are happy but seem unwilling or incapable of expressing their exuberance over their team's good fortune in a manner that most people would consider appropriate. This violence is erratic and defies logic. Unfortunately, these riots occur all 
too often They are usually on a relatively small scale, meaning contained to a small area along a street, park or thoroughfare, but not always. They typically last no more than a few hours.

There are other types of riots that veer from the description above. Socially Oppressive Riots (SOR) involves violence against persons whom perpetrators believe to be infringing on or encroaching on their territory. Additionally, violence perpetrated against persons simply because they display a level of difference that the perpetrators believe to be unacceptable and therefore intolerable, is most often present. Political Repressive Riots (PRR) entails violence carried out against people for the purpose of preventing them from achieving racial equality or preventing them from attempting to exercise rights as guaranteed by the U.S. Constitution. Often times, the principal instigators of the violence are members of local police departments, while other times they are white civilians seeking to maintain the status quo. In order to ensure the reader a firm grasp of this typology, a few examples of each sub-category from different periods in American history followed by a brief description are provided, some of which many scholars are familiar, while others are less widely known, but no less significant, thus resulting in an opportunity to educate the reader.

\section{Politically Repressive Riots (PRR)}

The 1965 Selma march on the Edmund Pettus bridge that May provides us with perhaps the most graphic images of violence perpetrated by the police of the last sixty years. Approximately 500 civil rights marchers who were drawing attention to the dearth of Black registered voters were met by 200 white police officers and state troopers, and subjected to tear gas, Billy-clubs and whips (Turner, 2018). This violent episode appeared on national television, resulting in widespread outrage. Determined to keep the voting rolls as they were, some of the state's law enforcement officers took to horseback and trampled scores of the protesters, knocking several of them consciousness.

Although the Selma march and other highly publicized civil rights demonstrations that were met with state violence have been chronicled in every form of media imaginable, the 1960s did not have a monopoly on Politically Repressive Riots. The Haymarket Riot is one that is deserving of some mention. During the early years of labor union organizing, police officers were often dispatched to the sites of protesting workers for the purposes of discouraging dissent. One noteworthy event occurred in May of 1886, when police officers killed four striking workers at the McCormick Harvesting Machine Co. in Chicago. The next day, a peaceful demonstration in Haymarket Square was underway when a bomb was reportedly thrown, killing eight police officers. Other officers opened fire, killing several more demonstrators and wounding an undetermined number. The incident became known as the Haymarket Riot.

Perhaps one of the least well-known riots of an earlier era unfolded in New Orleans, Louisiana in July 1866. The riot ignited when a crowd of Black freedmen marching for their liberties against the newly legislated Black Codes was brutally attacked by a mob of white Democrats. The mob included, among others, men from the city's police force, and a fair number of former soldiers from the Confederate Army. The freedmen marchers had former Union soldiers 
among them, thus the animosity was mutual. It is difficult to determine who shot first, but by the time federal troops had restored order, 44 people had been killed, the majority of whom were Black.

More than thirty years before the debacle in New Orleans was the anti-abolition riots in New York City in the summer of 1834. For several days in July whites rampaged through the city, torturing and raping blacks, and killing their white supporters and abolitionists. The worst rioting occurred in the Five Points area where dozens of houses, including the well-known St. Phillip's Church were burned to the ground. Determined to rid the city of the anti-abolitionist movement, no one was safe, if it was believed that he or she showed empathy for the efforts of the abolitionists. Over the course of several English sailors and Black slaves were captured and mutilated.

\section{Socially Oppressive Riots (SOR)}

Four years after the ordeal in Selma, in an entirely different part of the country in Greenwich Village, New York City police officers raided the Stonewall Inn, a known gay bar and commenced to beating and pummeling its occupants. Cop fighting ensued, as contrary to popular belief, the patrons did not go easy. The roughhousing spilled onto the street. During the melee, officers ransacked the building and destroyed property resulting in hundreds of dollars, worth of damage. The attack on its patrons was unprovoked. The raid was in absence of a crime. And the violence was malicious and indiscriminate.

Three thousand miles away in California and twenty-five years earlier, Los Angeles erupted into one of the worse riots of the period, in May of 1943. As the city's Latino population continued to increase due to the plethora of jobs owing to nearby shipyards and the burgeoning service industry, white Los Angelinos, especially white men began to grow visibly uncomfortable with the Mexican presence. For ten consecutive days armed sailors, civilians and in some cases, police officers cruised neighborhoods in search of "zoot-suiters"-flamboyant, young Mexican American males dressed in baggy pants and long-tailed coats. Kids as young as twelve years old were dragged from movie theaters and diners and beaten. Others were accosted and had their clothes torn off. One LA newspaper even printed a guide on how to "de-zoot" a zoot-suiter.

Arguably, the most widely broadcast and well-documented SOR of the decade, occurred in the city of Chicago a year earlier at the Democratic National Convention in 1968. Thousands of activists and left-wingers, many of whom were white, descended on Chicago to protest the war in Vietnam and other injustices. The city's mayor, Richard J. Daley, vowed to keep the Students for a Democratic Society (SDS), the country's largest left-wing group as well as any out-oftowners from disrupting the convention and embarrassing the city of Chicago. Chicago was Daley's town and he made clear that anyone looking to make trouble would be dealt with appropriately. The result: Hundreds of members of the Chicago police department waded into huge crowds, beating and whacking anyone upside the head who resembled a hippie, protestor or innocent bystander who happen to be in the police rioters', crossfire. The spectacle was captured on live TV and broadcast around the world. Scenes of police officers dragging people by their hair 
and clubbing protestors about the head and body outraged many viewers and gave the country a blackeye in the international community.

Of, course, no intelligent discussion of riots can be had without revisiting the atrocity that occurred in northeast Oklahoma. Over the course of 18 hours from May 31-June 1 in 1921, a white mob intent on defending the honor of a white woman who falsely accused a Black teenager of rape, descended on the Black residents and their thriving business district known as the Black Wall Street, situated in the predominantly Black Greenwood community of Tulsa, Oklahoma. Large groups of whites - some of whom were deputized and given pistols and rifles by city officialscommitted numerous acts of unspeakable violence against Black men, women and children. Homes and buildings were burned to the ground (Johnson, 2020; Harris and Carser, 2019). People were killed, and thousands left homeless as a result of this racially driven riot on the part of crazed whites. Each of the cases described above involved violence on the part of agents of the state or white civilians against those whom the perpetrators either deemed deviant, uppity and seeking to exercise rights long afforded whites.

\section{Stop calling them riots!}

The violence that has unfolded in the streets in many urban enclaves throughout the country in 2020, are anything but riots. One might be tempted to file them under the category of uprisings, revolts or rebellions - meaning the raising up of large numbers of people in response to a legitimate grievance or grievances that those in power have, for years, either ignored or not taken seriously. ${ }^{5}$ Contrary to popular belief, when Los Angelinos erupted in South Central in 1992, they did so not in response to the 1991 brutal beating of Rodney King on the part of four Los Angeles police officers per se, which was captured on video for all the world to see, but because residents were fed up with a system that was viewed as corrupt, oppressive, and that had, once again failed them despite the existence of clear visual evidence. The upheaval occurred, not in 1991, in the wake of the beating of King, but a year later when the four guilty LAPD officers were tried and acquitted of any wrongdoing. It should be made clear however, that the acquittal of the four police officers merely represented the straw that broke the proverbial camel's back. In other words, while the beating of King was not the precipitating event, nearly every Black-led urban uprising, beginning with that which occurred in Harlem in 1964 was sparked by a police officer's beating or shooting of a Black motorist and/or pedestrian.

In the case of Los Angeles, the city had long endured a slow burn, that after years of simmering was a pot ready to boil over. Many Black and Brown residents there lived under conditions that were ripe for explosion. For decades, many Black and Brown Angelinos experienced high levels of unemployment and suffocating poverty, severe segregation in housing, overcrowding in public schools, lack of access to adequate health care facilities and harsher policing than that experienced by non-people of color. The inferior position to which Black and Brown people had been consigned was not appreciably different in the early 1990s than in 1965 when the community of Watts went up in flames. The acquittal of the four police officers in 1992 was the spark that ignited the flame. Those revelers had legitimate grievances that went 
unaddressed for decades. Again, the upheaval that occurred that year was driven by the socioeconomic conditions, under which many minority residents were forced to endure over many years--conditions that were supposed to have been eradicated or at least addressed in the wake of the 1965 uprising, but for the most part, were not. ${ }^{6}$

In the early 2000s, the city of Cincinnati experienced a level of street-protest and violence that had not occurred since Dr. King's assassination in 1968. Between 1995 and 2001, fifteen African American males, all under the age of 40, were killed by members of the Cincinnati Police Department. Interestingly, no whites of any age were killed by police officers over that span. On April 7, shortly after 2:00 a.m. Timothy Thomas, the fifteenth African American male, was shot by a police officer when officers cornered him in an alley, after giving chase. Protestors took to the streets in the days that followed. Violence erupted, resulting in damages estimated at $\$ 13.7$ million, dozens had been injured, and 78 buildings destroyed. Cincinnati residents had experienced many of the same things as Los Angelinos leading up to the uprising that lasted nearly a week. One wonders why the previous fourteen shooting deaths of Black males - coupled with sweltering poverty, high unemployment, and entrenched residential segregation-were not enough to ignite an uprising (Upton, Jeffries and McDaniels-Wilson, 2007). In other words, why did it take the killing of 15 Black men before African Americans concluded enough was enough? While Blacks in other cities may have wondered aloud about Black Cincinnatians' seemingly high tolerance for pain and suffering, many agreed that, given the challenges that Blacks encountered on a daily basis, the violence that ensued in early April of 2001 was long overdue.

\section{Theoretical Significance: Why is this important?}

Words matter; they are important because they influence people's thinking. If it is true, as Aristotle argued centuries ago, that the ability to reason is what separates humans from animals, then there should be universal agreement that words and their meaning are the building blocks of intelligent discourse. Moreover, by limitation and selection they-- meaning words and their definitions-oftentimes shape and govern the statement of the problem and therefore regulate the entire argument as well as the conclusions that follow. In short, words and their meanings are tools, whose truth and power emanate from their success in mediating between humans and the phenomena being placed under close examination.

For many people, the word riot, prompts certain unfavorable images. When those charged with presenting the nightly news, refer to Black-led unrest as riots, they unwittingly or deliberately begin the process of crafting a narrative that impacts the way the insurgents are viewed by the general public. This goes for the academics as well as the talking-heads that are seen on programs like Meet the Press and other shows where political discussions are the order of the day. Because many Americans aren't the discerning thinkers that we'd like them to be, their opinions are, by and large, often formed by what they see on TV, what they see and read on the internet and what they read in the newspaper or hear on the radio. 


\section{Media framing ${ }^{7}$ and Black Unrest}

Historically, news coverage of uprisings features those images that contain the greatest shock value, that compel viewers to remain tuned into the broadcast. After all, news organizations are as interested in generating revenue as they are in reporting the news. For example, images of burning buildings and stores being looted are featured prominently in many telecasts, albeit oftentimes, absent of any substantive context. Whether or not this is by design is a question that merits consideration. Although, there have been few revolutions in world history where setting buildings ablaze and looting have not occurred, this type of behavior, when perpetrated by Blacks in the U.S. specifically, is used as an excuse to dismiss the legitimacy of the unrest, and by extension, their grievances.

Anyone who believes that the American Revolution and the Civil War, for example were devoid of looting and destruction of property are more than a little naïve and should be encouraged to read James Loewen's (2007) book Lies my teacher told me. Furthermore, if an uprising is a prelude to a revolution--and if what founding father Thomas Jefferson said is true--that when the government starts to behave antithetical to the people's interests, the people have a right to rise up, overthrow that government and begin anew, then why are Blacks villainized when their outrage manifests in revolt? For those whites who are oblivious to the plight of African Americans or simply unsympathetic to their predicament, in their minds, the uprising is not an uprising, but a riot, an opportunity to steal a television set, microwave or some other such electronic device or appliance that can be snatched up and hauled away quickly. Such thinking was initially promulgated by Edward C. Banfield in his acclaimed 1970 book The Unheavenly City: The Nature and Future of Our Urban Crisis who ignorantly titled one of his chapters "Rioting Mostly for Fun and Profit" (Banfield, 1970). For whites like Banfield and others, seeing men and women stampede into businesses and trample over one other as they loot and pillage one establishment after another conjures up images of savages. In fact, it is not atypical to hear commentators use the word zoo to describe the looting. Bombarded with these kinds of images, combined with an underdeveloped and/or inaccurate narrative, viewers are encouraged to see the revelers as criminals at best and animals at worst. By framing the revelers this way, the storytellers, make it difficult for revelers to garner empathy from those who initially may have been open-minded to seeing things from the revelers' standpoint. Consequently, white viewers see revelers, not as the aggrieved, but as thieves and lawbreakers, which in turn breeds resentment and hostility.

\section{The Resulting Impact}

News coverage features the sensational aspects of uprisings in order to keep viewers glued to the television set rather than educating the public on the root causes of the violence. By framing the goings-on in this way, elites are able to pretend that the problems over which the aggrieved are outraged, don't actually exist. And if persons in power can convince the white public that all is well, that any such notions of entrenched and systemic issues of racial inequality are simply figments of Black people's imagination, then the ruling elite will not be compelled to earmark any funds toward ameliorating those problems-because they don't exist. Anthony Giddens pointed 
out long ago, not surprisingly, that the mass media is often employed by the state to manipulate populations in order to further the power elite's agenda (Cassell, 1993; Giddens, 1985). Finally, and even more disconcerting, is that students of politics need to understand what those in power know all too well, and that is, if those who control the country's ruling institutions are able to convince the white public that the insurrectionists are criminals and savages against which the white public needs to be protected, rather than patriotic Americans who are demanding that they be afforded all of the rights that are guaranteed them in the United States Constitution, it makes it easier for the state come in and quell any and all such uprisings, even if it means maiming, crippling and killing fellow Americans in the process.

\section{Conclusion}

The events of the past several years have done much to shatter our confidence in the system. Not only have we witnessed and/or learned of the murders of countless unarmed Black men, women and children by police officers, but we have endured four years of presidential politics that has, more than any other White House regime since World War I, resembled that of the racist Woodrow Wilson administration of the early 1900s. That Joe Biden and Kamala Harris's eked out a win over Donald Trump and Mike Pence offers some a sigh of relief. At the same time, that Biden and Harris did not cruise to the landslide victory that they were seemingly set up to enjoy is also very telling.

The best response to our current predicament is to not only acknowledge and address the problems that are afflicting our society as well as the people who are fanning the flames of hate, but to appreciate the resiliency shown by a people, Black people, who for 400 hundred years have been forced to navigate a terrain laden with landmines. While systemic racism and inequality persists as an overarching reality, one would think that mitigating responses could be worked out in the middle ground between structure and agency. In 1968, the venerable, George F. Kennan said this during a speech at Princeton University: "We are faced with a whole series of national problems, each of which, if not soon met in some adequate manner, has the capability of bringing most grievous, perhaps mortal damage to our national life. Yet to none of which has our response as a nation been to date in any way adequate" (New York Times, December 4, 1968, p. 62). Sadly, fifty-two years later, Kennan's words are no less true today than they were five decades ago.

\section{References}

Banfield, E. C. (1970). The Unheavenly City: The Nature and Future of Our Urban Crisis Boston: Little Brown and Company.

Cannon, L. (1997). Official Negligence: How Rodney King and the Riots changed Los Angeles and the LAPD. New York: Basic Books.

Cassell, P. (ed.). (1993). The Gidden Reader. New York: Red Globe Press.

Castenada, E. and C. L. Schneider. (eds). (2017). Collective Violence, Contentious Politics, and Social Change: A Charles Tilly Reader. New York: Routledge. 
Downes, B. T. (1970). "A critical re-examination of the social and political characteristics of riot cities. Social Science Quarterly 51 (December): 349-360.

Feagin, J. R., and Hahn, H. (1973). Ghetto Revolts: The Politics of Violence in American Cities. New York: Macmillan.

Geschwender, J. A. (1964). Social Structure and the Negro Revolt: An Examination. Social Forces. Vol. 43, no. 2. (December).

Giddens, A. (1985). The Nation-State and violence. Berkeley: University of California Press.

Griffin, N. (2020). The Year of Dangerous Days: Riots, Refugees, and Cocaine in Miami 1980. New York: Simon \& Schuster, Inc.

Gurr, T. (1989). Protest and Rebellion in the 1960s: The United States in World Perspective in T. Gurr (ed.) Violence in America Volume. 2. Protest, Rebellion, Reform. (California: Sage, 1989), 101-130.

Gurr, T. (1970). Why Men Rebel. Princeton: Princeton University Press.

Harris, D. and A.R. Carser. (2019). The Tulsa Race Riot. Minnesota: Abdo Publishing.

Hunt, D. (1996). Screening the Los Angeles 'riots'. England: Cambridge University Press.

Janowitz, M. (1967). The Social Control of Escalated Riots. Chicago; University of Chicago Press.

Johnson, H. B. (2020). Black Wall Street 100: An American City Grapples with Its Historical Racial Trauma. Texas. Eakin Press.

Loewen, J. (2007). Lies my Teacher told me. New York: Atria Books.

Lowry, I. and P. A. Morrison. (1992). A Riot of Color: The Demographics Setting of Civil Disturbance of Los Angeles. Santa Monica: Rand Publishing.

Madhubuti, H. (1993). Why L.A. Happened. Chicago: Third World Press.

Millett, N. (2013). The Maroons of Prospect Bluff and Their Quest for Freedom in the Atlantic World (Contested Boundaries). Gainesville: University of Florida Press.

Mulroy, K. (1993). Freedom on the border: The Seminole Maroons in Florida, the Indian Territory, Coahula, and Texas. Lubbock: Texas Tech University Press.

Porter, B. D. and Dunn, M. (1984). The Miami Riot of 1980. MD: Lexington Books.

Stone, C. N. (1989). Regime Politics: Governing Atlanta, 1946-1988. Lawrence, KS: University Press of Kansas.

Turner, J. P. (2018). Selma and the Liuzzo Murder Trials: The First Modern Civil Rights Convictions. Ann Arbor: University of Michigan Press.

Upton, J., Jeffries, J.L. and C. McDaniels-Wilson. (2007). The 2001 Cincinnati Uprising. International Journal of Africana Studies. Vol. 13 No. 1 (Spring/Summer): 1-14.

${ }^{1}$ Five hypotheses dominated the literature. They were: 1) As a group experiences a worsening of its life conditions, it will become increasingly disgruntled until it eventually rebels; 2) As a group experiences an improvement in its life situation, it will also experience a rise in its level of desires. The latter will rise more rapidly than the former, leading to dissatisfaction and rebellion; 3) As a group experiences an improvement in its lifestyle, while at the same time seeing another minority group experiencing a more rapid rate of improvement, it will become dissatisfied with its rate of improvement and rise up; 4) As a group experiences enhanced life chances followed by a sharp reversal of this improvement, it will become dissatisfied with its rate of improvement and revolt; and 5) A group that possesses a small number of status attributes, which 
are differently ranked on the various status of hierarchies will be dissatisfied and prone toward revolt. For more detail, see James A. Geschwender, Social Structure and the Negro Revolt: An Examination of some Hypotheses. Social Forces vol. 43, no. 2 (December).

${ }^{2}$ The words African American and blacks are used interchangeably throughout according to sound and context as well as to avoid repetition.

${ }^{3}$ A late December three day Black-led uprising occurred after police officers Luis Alvarez and Louis Cruz, entered a video game room as part of a routine check for narcotics and while there Alvarez shot and killed 21 year-old African American Nevell Johnson.

${ }^{4}$ The 1989 uprising (January 16-21) was sparked after police officer William Lozano shot Clement Lloyd, who was running away from another officer and according to Lozano trying to run over him with his bike. Lloyd crashed into a car and his passenger, Allan Blanchard, was also killed.

${ }^{5}$ In 1967, President Lyndon Baines Johnson authorized the forming of the Kerner Commission, formally known as the National Advisory Commission on Civil Disorders to identify the root causes of the uprising that occurred in Detroit in August of that year. To say that the Kerner report was a major document would be an understatement; it declared that the policies of racial integration pursued by the federal government since World War II were an utter failure. Perhaps the Kerner's Report's most controversial basic conclusion, was that "Our nation is moving toward two societies, one black, one white-separate and unequal." "White society is deeply implicated in the ghetto," the Kerner Report concluded. "White institutions created it, white institutions maintain it, and white society condones it." Despite this finding, very little was done in way of systematic and sustainable programming to address the many issues raised in the report.

${ }^{6}$ California Governor Ronald Reagan appointed the Governor's Commission on the Los Angeles Riots [as they were called], otherwise known as the McCone Commission, after its chairman, former CIA director John A. McCone. The Commission's outcome had little to no impact on the lives of the state's historically marginalized residents. To this day, there are still areas of Watts that were scorched, that remain that way. ${ }^{7}$ Media framing is the packaging of words and images in such a way as to encourage certain interpretations and discourage others. While news is often thought to be objective and free of bias, this is almost never the case. In fact, many news stories are value laden in both their production and content. News is not a precise representation of reality but rather a reconstruction from various angles of a small sample of reality. This is not to say that media personnel deliberately lie or misrepresent the truth, although some do, but that reporters and journalists by covering certain stories, using $\mathrm{x}$ amount of sources from different angles are constructing reality through a selective, and dare I say, filtered process. To be fair, they are oftentimes constrained both by the work culture, limited resources and their relationship to shareholders and manager. 